\title{
A Fibro Naso-Laryngoscopy Assessment on Hoarseness: Morphological finding of the larynx by direct visualization
}

\author{
Hendarto Hendarmin, Hartono Abdoerrachman
}

\begin{abstract}
Abstrak
Pemeriksaan prospektip untuk manfaat pemakaian fibro Nasa-Laringoskop guna menilai kelainan di laring telah dilakukan terhadap 41 penderita dengan keluhan suara serak. Pemeriksaan ini memperbaharui laporan penelitian terdahulu, yang menggunakan Laringoskop kaku. Dari hasil yang didapat terlihat bahwa tidak semua suara serak disebabkan oleh kelainan pita suara. Pemeriksaan tambahan untuk melengkapi diperlukan guna menegakkan diagnosis yang lebih akurat dan tepat. Dari 41 kasus suara serak didapatkan 30 dengan kelainan morfologi di laring dan 11 kasus dengan disfonia fungsional.
\end{abstract}

\begin{abstract}
A prospective study evaluated potential use of fibro Naso-Laryngoscope to assess the morphology of the larynx had been conducted in patients with hoarse voice symptom, due to variable causes. Forty one subjects were examined and assessed prior to treatment to obtain the exact and definite cause of hoarseness. This study updates the previously reported findings by former investigators using rigid Laryngoscope. From the result obtained, it was shown that hoarseness was not always due to vocal folds entanglements. Additional informations from anamnesis as well as clinical and adjunctive examinations were needed to confirm the exact or definite cause of hoarseness. From 41 subjects, it was revealed that 30 cases had morphological anomalies, while 11 cases were functional dysphonia
\end{abstract}

Keywords: fibro Naso-Laryngoscopy, hoarse voice, morphological larynx.

Voice is the musical sound produced by vibration of the vocal cords in the larynx by air from the lungs, and this process is known as phonation. In the language, we acknowledge voice to be an exclusively human attribute. Besides pitch and volume, the voice has subtle qualities which convey the condition of the vocal cords.

Dysphonia refers to impaired voice, that is, voice deviating in some way from the normal. What is important is any sudden change in the voice which makes it sound and feel different from what it has been in the past. We can say in general that the essential attributes

Department of Otorhinolaryngology. Faculty of Medicine, University of Indonesia/Dr. Cipto Mangunkusumo Hospital, Jakarta, Indonesia of normal voice are basically audibility (appropriate volume), pleasing quality, and pitch appropriate to age and sex. Moreover, dysphonia is perceptually confined to deviations to grade of deviation $(G)$, roughness $(R)$, breathiness (B), aesthenicity (A), and strain (S) ${ }^{1,6}$. Hoarseness is combination of breathiness and harshness, and most voice deviations can be placed in one of these catagories, since they do not include so great number of different qualities.

Hoarseness is a symptom and not a disease, and is one of the most important symptoms in throat diseases, because in its chronic form it may be an early warning of serious disease in the larynx and elsewhere. Hoarseness may be defined as a rough, harsh, quality of voice which is lower than normal in pitch for a person 2 . Hoarse voice is not always due to laryngeal anomalies, particularly the vocal folds, and that each 
hoarseness should be confirmed for morphological anomalies of the larynx. To have a definite conclusion of the hoarse voice, provision of additional informations from anamnesis as well as clinical and adjunctive examinations were needed to confirm the exact cause of hoarseness.

Some experts had been conducting and reported their results concerning hoarseness ${ }^{3,4,5}$ and yet no one reported morphological-basic investigation and documentation to visualize the exact cause of hoarseness for those subjects. McAllister et al. (1994) has reported that from 60 children with hoarse voice $23 \%$ was due to posterior glottal chinks and $10 \%$ was due to nodules of the vocal cords. While Abdoerrachman et al. (1995) in his 3 years data collection which covered 442 subjects with various laryngeal abnormalities reported that vocal cord polyps were mostly found $(26.47 \%)$, followed by recurrent nerve paralysis $(21.94 \%)$. Both investigations were without photographic documentation.

In this paper direct visualization of the larynx of subjects with hoarseness were performed using fibro Naso-Laryngoscope to determine morphological anomalies of the larynx, and descriptive findings were reported with the photographic documentations.

\section{METHOD}

Subjects for the study were 41 cases with hoarseness due to variable causes, from both sex and age range between 15 - 75 years. All the patients were consulted to the private hospital of R.S. Khusus THT-Bedah YPR from December 1994 - August 1995, with hoarseness which lasted more than two weeks. Subjects were examined for thorough anamnesis, routine ENT check including indirect laryngoscopy by means of laryngeal mirror, laboratory blood and urine, were carry out. Chest X-ray examinations were performed whenever necessary. All the datas obtained were stored in computer.

The patients were then prepared and underwent examination procedure for direct visualization of the larynx by means of fibro Naso-Laryngoscope through the nose, using Olympus E.NF type I T 10 with power supply Olympus = CLE -10 , connected to Canon Photo-Camera with lens opening 15, and ASA 200 film. The procedure was performed under local anesthesia using Xylocaine spray and nasal decongestant of Adrenalin 1/1000 tampon, to determine the laryngeal abnormalities. The laryngeal-lesions were photographed for documentation. Finally, descriptive report of this study was then compiled.

\section{RESULTS}

Table 1 showed the distribution of the subjects in sex grouping. From 41 cases of hoarseness, male subjects were dominant compared to female.

Table 2 showed the distribution of samples based on age grouping. It was evidently shown that middle-age groups (26 up to 55 years) had predominantly hoarse voice complain.

Table 3 showed the description of fibro Naso-Laryngoscopy findings of the whole subjects. It was revealed that 30 cases had variable laryngeal morphological anomalies, while 11 cases were functional dysphonia with uncertain laryngeal anomaly.

Table 1. Sample distribution based on sex-grouping

\begin{tabular}{lcc}
\hline Gender & $\mathrm{N}$ & $\%$ \\
\hline Male & 24 & 58.54 \\
Female & 17 & 41.46 \\
\hline Total & 41 & 100 \\
\hline
\end{tabular}

Table 2. Sample distribution based on age - grouping.

\begin{tabular}{lr}
\hline Age & $\mathrm{N}$ \\
\hline $15-25$ & 2 \\
$26-35$ & 10 \\
$36-45$ & 9 \\
$46-55$ & 9 \\
$56-65$ & 7 \\
$66-75$ & 4 \\
\hline Total & 41 \\
\hline
\end{tabular}

Table 3. Laryngeal abnormalities exposed by fibro NasoLaryngoscopy.

\begin{tabular}{lr}
\hline Abnormalities & N \\
\hline The vocal cords : & \\
paresis of V.C. & 13 \\
malignancy & 6 \\
edema of V.C. & 2 \\
nodule of V.C. & 1 \\
The epiglottis : & \\
cyst & 5 \\
edema of epiglottis & 3 \\
Functional dysphonia & 11 \\
\hline
\end{tabular}




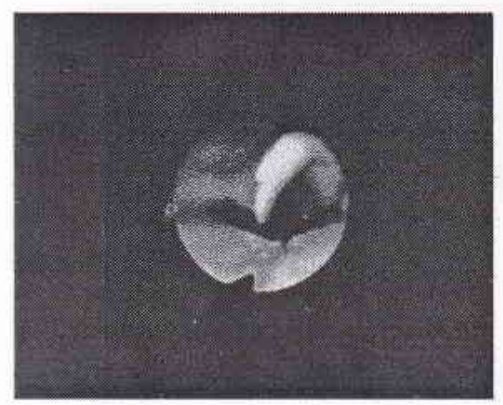

Figure 1. Asymetrical of the epiglottis with normal vocal cords.

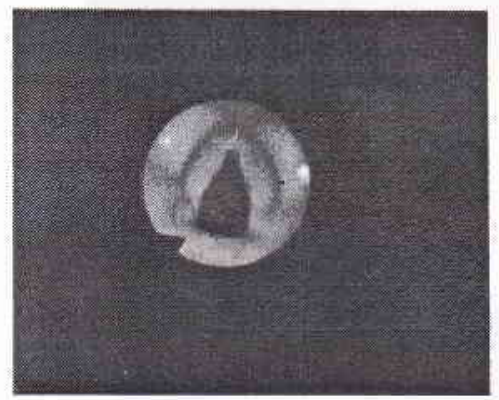

Figure 3. Swollen and hypervascularization of both vocal cords, as usually found in the functional dysphonia.

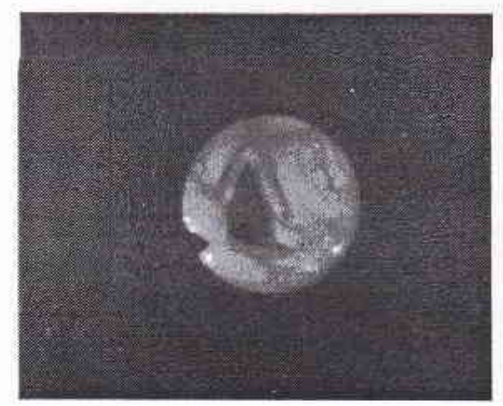

Figure 5. "Singers Node". Nodule of the vocal cords.

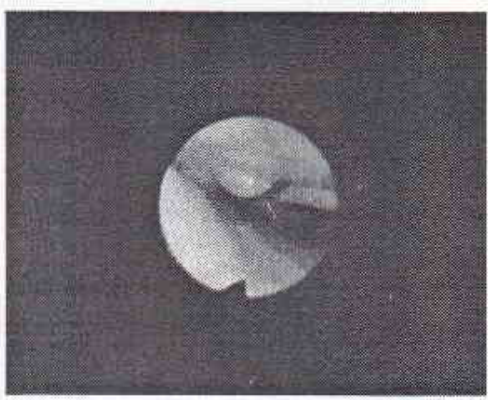

Figure 2. Cyst of the epiglottis.

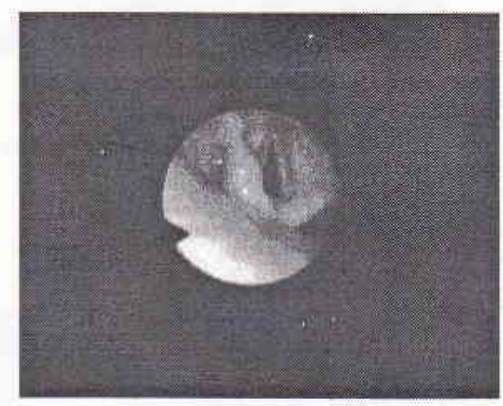

Figure 4. Unilateral vocal cords paralysis with asymetrical of the arythenoid.

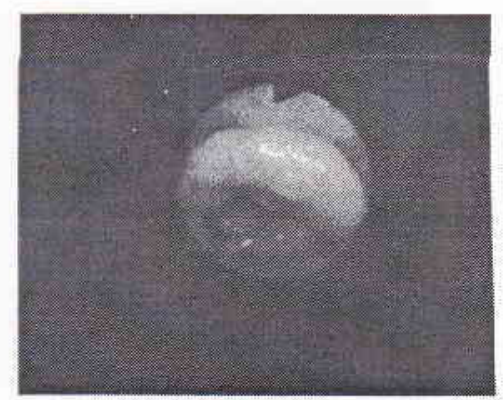

Figure 6. Edema of the epiglottis and both of arythenoids as seen in laryngeal tuberculose, with clinical chest X-ray finding: pulmonary tuberculosis with miliary spread. 


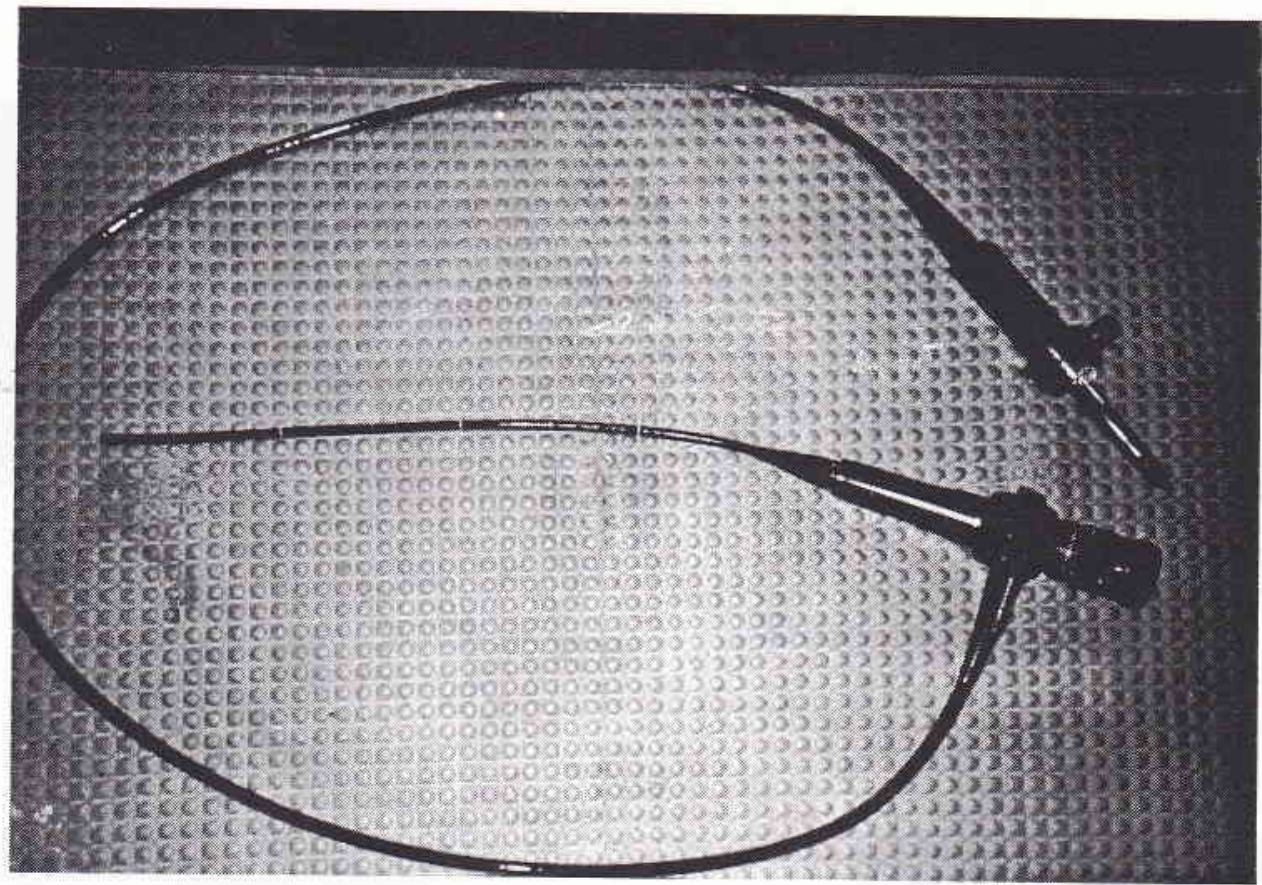

Figure 7. The Naso-Laryngoscope Olympus E.NF type I T10.

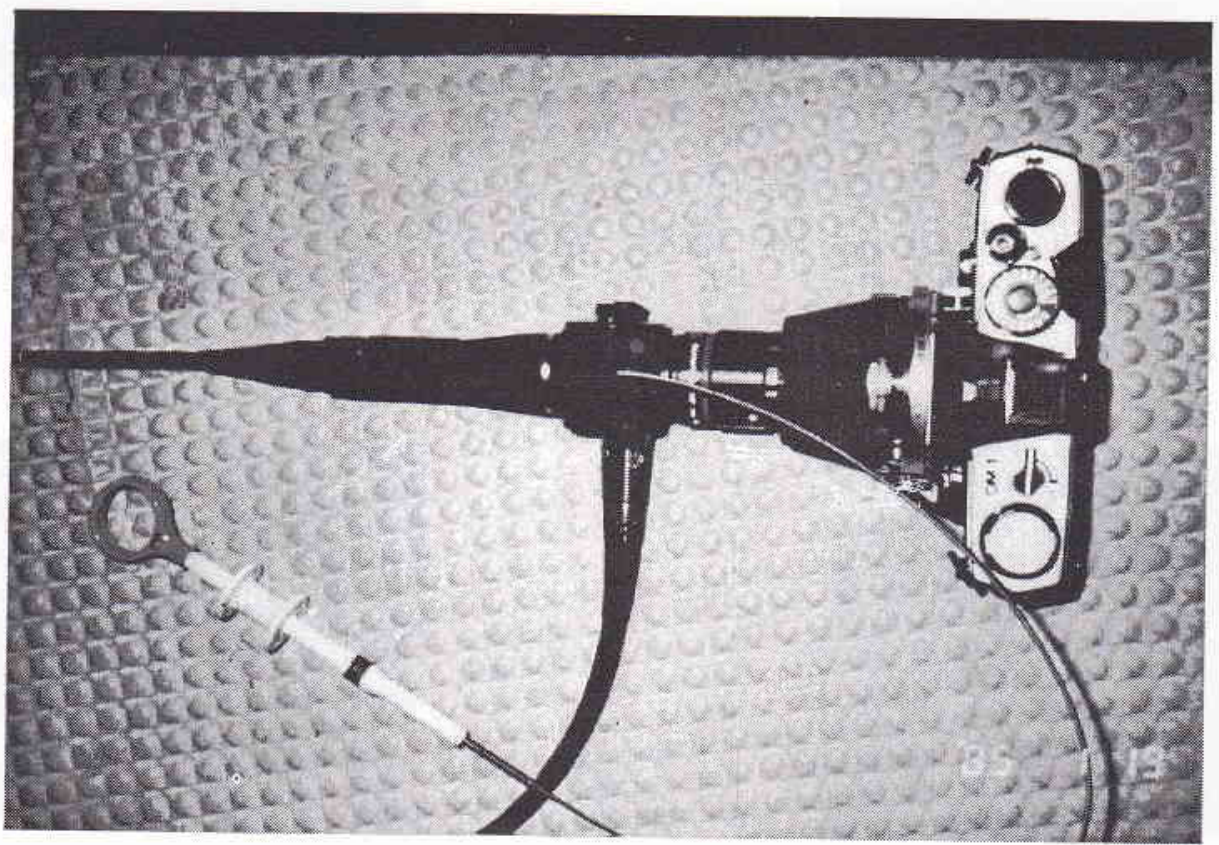

Figure 8. The attachment of camera to the Naso-Laryngoscope for documentation purpose. 


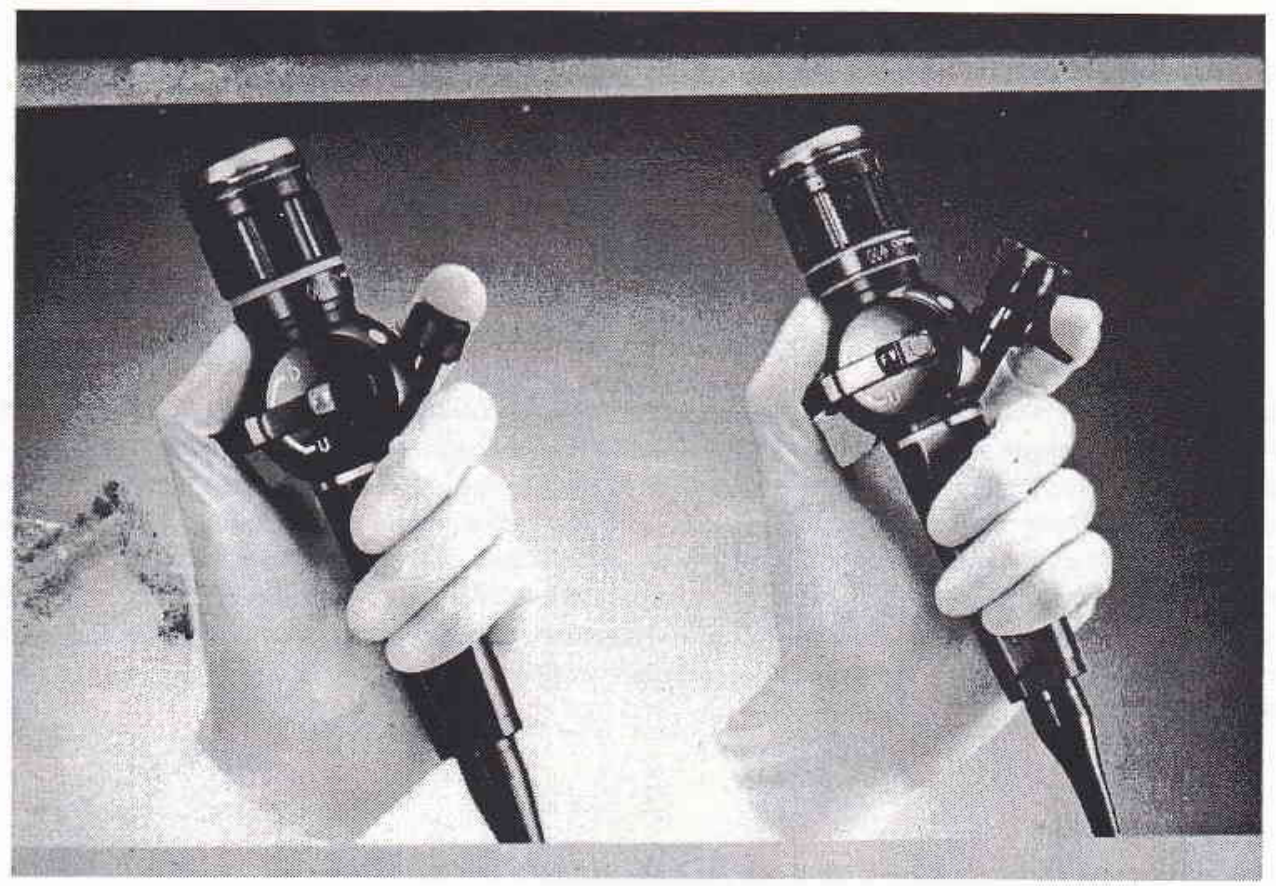

Figure 9. Position of hand-grip.

\section{DISCUSSION}

Dysphonia can be classified into 2 types, type 1 : the functional dysphonia, which was caused by hyperkinesia or habitual and vocal abuse due to occupational demand. The type of dysphonia is the most common and perhaps the most easily reversible type of voice disorder. Direct laryngoscopy reveal uncertain abnormalities of the larynx, particularly the vocal cords. Type 2: pathological dysphonia, which was caused by variable diseases of the larynx, from benign lesion to malignancy.

From this study evidence, patients with hoarseness were mostly found in middle age groups (26 - 55 years), with male dominance. From Table 3 , it was shown that not all of hoarseness were due to lesions of the vocal cords, $8(19.5 \%)$ were lesions on the epiglottis. Functional dysphonia without any clear vocal cords abnormalities were found in $11(26.8 \%)$ patients. This might be caused by vocal abuse due to occupational demand, as most subjects were those who need to exagerate used of voice.

Photographic documentations of the larynx were also exposed to show the lesions at or around the vocal folds.
In this paper it was evidently shown that the use of fibro Naso-Laryngoscope is beneficial and is a promising tool to determine the exact and definite diagnosis of hoarseness by visualizing and documenting photographically the larynx with its lesions. Moreover, the procedure is not frightening, painless, inexpensive and easy to perform.

\section{REFERENCES}

1. Hirano M. Clinical Examination of Voice. Disorders of Human Communication 1981; 5: 48-57.

2. Boies LR. Hoarseness. Fundamentals of Otolaryngology 1969;3:387-95.

3. McAllister A, Sederholm E, Sundberg J, Grammig P. Relations between Voice Range Profiles and Physiological and Perceptual Voice Characteristics in ten-year old Children,J Voice 1994; 8(3): 230-9.

4. Ramadan HH, Wax MK. Laryngeal tuberculosis. A cause of Stridor in Children. Arch Otolaryngol Head Neck Surg 1995; 121(1): 109-12.

5. Hartono Abdoerrachman. Acoustical and Clinical Assessment of Voice Quality with Laryngeal Pathology. Med J Indon 1995; 4: 90-7.

6. Sakata T, Kubota N, Yonekawa H, Imaizumi S, Niimi S. GRBAS Evaluation of Running Speech and Sustained Phonations. Ann Bull RILP 1994: 28: 51-6. 